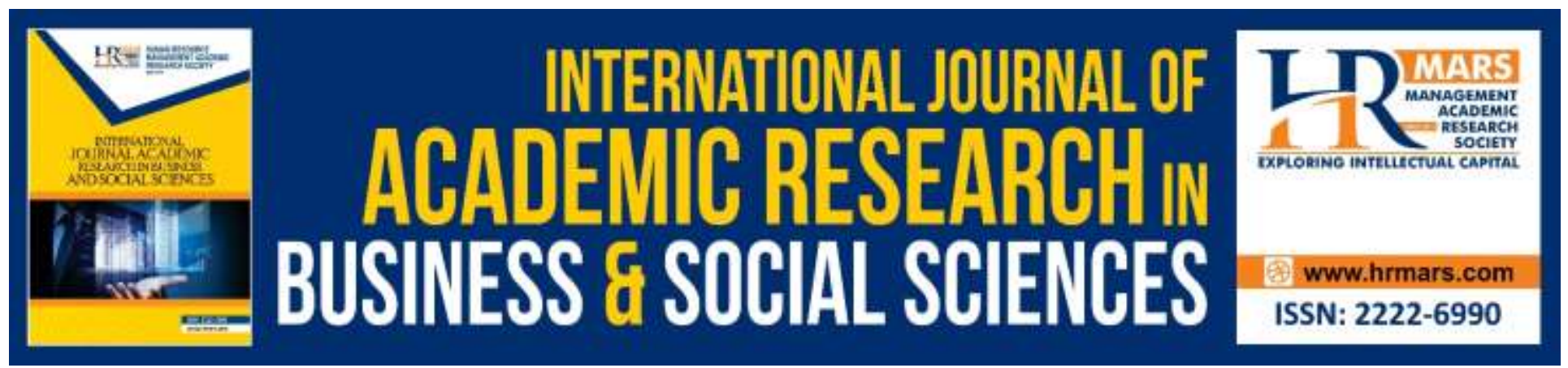

\title{
Effects of Corporate Governance on Delinquency Management of Microfinance Banks in Southwest, Nigeria
}

\section{Rasheed Alade Abdulai, Mojisola Abere and Samson Oluwole Olowo}

To Link this Article: http://dx.doi.org/10.6007/IJARBSS/v10-i5/7215

DOI:10.6007/IJARBSS/v10-i5/7215

Received: 19 March 2020, Revised: 22 April 2020, Accepted: 30 April 2020

Published Online: 13 May 2020

In-Text Citation: (Abdulai et al., 2020)

To Cite this Article: Abdulai, R. A., Abere, M., \& Olowo, S. O. (2020). Effects of Corporate Governance on Delinquency Management of Microfinance Banks in Southwest, Nigeria. International Journal of Academic Research in Business and Social Sciences, 10(5), 438-455.

Copyright: (C) 2020 The Author(s)

Published by Human Resource Management Academic Research Society (www.hrmars.com)

This article is published under the Creative Commons Attribution (CC BY 4.0) license. Anyone may reproduce, distribute, translate and create derivative works of this article (for both commercial and non-commercial purposes), subject to full attribution to the original publication and authors. The full terms of this license may be seen

at: $\underline{\text { http://creativecommons.org/licences/by/4.0/legalcode }}$

Vol. 10, No. 5, 2020, Pg. 438 - 455

http://hrmars.com/index.php/pages/detail/IJARBSS

JOURNAL HOMEPAGE

Full Terms \& Conditions of access and use can be found at http://hrmars.com/index.php/pages/detail/publication-ethics 


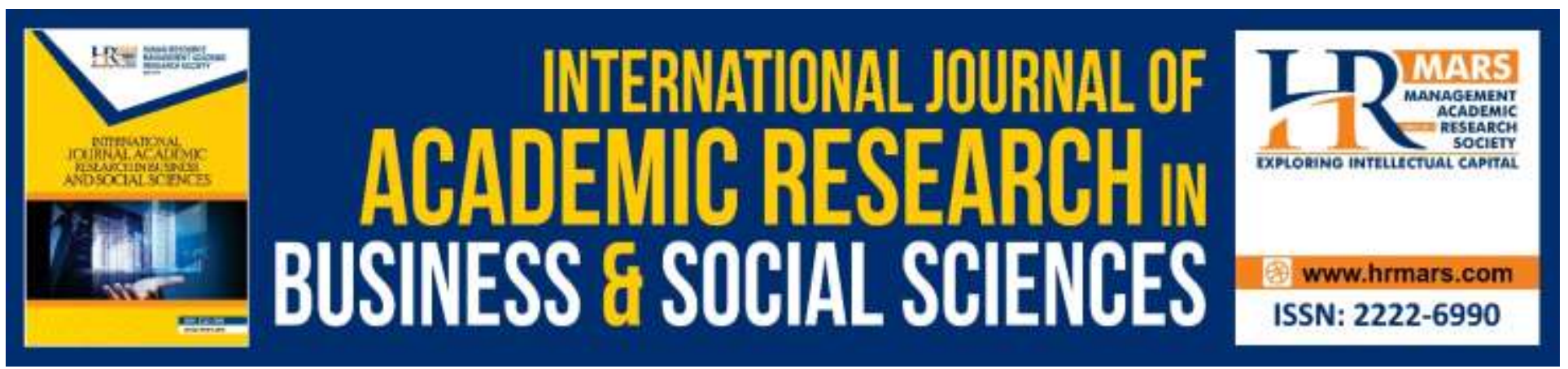

\title{
Effects of Corporate Governance on Delinquency Management of Microfinance Banks in Southwest, Nigeria
}

\section{Rasheed Alade Abdulai ${ }^{1}$, Mojisola Abere $^{2}$ and Samson Oluwole Olowo ${ }^{3}$}

${ }^{1}$ Department of Banking and Finance, Faculty of Financial and Management Services, Polytechnic of Ibadan, P.M.B. 22, Ibadan, Oyo-State, Nigeria, ${ }^{2}$ Department of Finance, Faculty of Management Science, Ekiti State University, P.M.B. 5363, Ado-Ekiti, Ekiti State, Nigeria, ${ }^{3}$ Department of Finance, Faculty of Management Science, Ekiti State University, P.M.B. 5363, Ado-Ekiti, Ekiti State, Nigeria

\begin{abstract}
The study investigated the effects of corporate governance on delinquency management of microfinance banks in Nigeria with the aim to examine the impact of board size and board composition on delinquency management. The study applied Static panel regression estimate which involved pooled regression, fixed effect estimate, random effect estimate, Hausman test as the main estimation technique. Data on corporate governance (proxied by board size and board composition) and delinquency management (proxied by default rate) were obtained from Annual Financial Statement of respective microfinance banks over a period of seven (7) years from 2012 to 2018). The result revealed that board size has negative and significant effect on default rate and board composition has a negative and an insignificant effect on default rate. The result implies that bank managers should increase their board size with more management skills and professionalism, making it very difficult for the CEO to manipulate the board. The study concluded that corporate governance has negative effect on delinquency management of microfinance banks in Nigeria. The study recommended that management of microfinance banks should regulate the size of the board which should not be too large and must consist of highly skilled and competent professionals who are conversant with oversight function.
\end{abstract}

Keyword: Corporate Governance, Credit Policies, Delinquency Management, Microfinance Bank, Nigeria.

\section{Introduction}

Corporate governance focuses on the way organisations are managed and controlled. This includes the best practices established and followed by organisations to ensure its operations are governed. Basically, corporate governance is the process that ensures how a firm is directed, controlled and held accountable. This involves interaction among stakeholders dealing with the organisation directly 
or indirectly including employees, shareholders, creditors, subcontractors and long-term suppliers (Brownbridge, 2007; Ndumai, 2013). Aliu and Gakure (2014) opine that corporate governance involves a system by which financial institutions such as microfinance banks relate to their customers and stakeholders to improve their quality of life. Therefore, good corporate governance ensures transparency, accountability and fairness in financial transactions and reporting (Oyewole, Olusanmi \& Owolabi, 2015). Corporate governance is not only limited to corporate efficiency, it also relates to a much wider range of microfinance banks' strategies and life cycle development (Unegbu, 2004). Microfinance banks record negative experiences of failure around the globe in recent time which gives credence to the need for good and sound corporate governance practices (Oyewole et al, 2015). According to Fernando (2006), microfinance banks (MFBs) around the world witness several failures as a result of high incidence of non-performing loans, weak management and poor governance. Shleifer, Andrei and Vishny cited in Ndumai (2013) assert that the sheer scale of fraud, embezzlement and graft in some failed microfinance banks has brought into question the reliability and effectiveness of present-day operational and compliance control mechanism and financial reporting systems of microfinance banks.

The impact of corporate governance on microfinance bank seems unequally dispersed among countries. Some microfinance banks have become very significant in size and serve a good number of Small and Medium Enterprises (SMEs) customers, like the Grameen Bank in Bangladesh, or BRI in Indonesia, while other microfinance banks remain relatively small or even cease to exist (Cicea \& Hincu, 2009). An important mechanism of governance is the quality of the board of directors. Accordingly, leadership characteristics of MFIs have great impact on their performance (Waithakam Gakure \& Wanjau, 2013). The primary objective of every microfinance bank is to operate profitably in order to maintain its stability and improve performance and sustainability (Impact reporting and investment standards, 2010). However, existence of high levels of loan delinquency problem in microfinance industry in most countries negatively affects the level of services to SMEs (Ditcher, 2003).

The governance of corporate microfinance bank plays a principal role in ensuring that the bank keeps to its mission of serving SMEs and other customers (Moauro \& Spaggiari, 2011). Good corporate governance in microfinance banks is expected to underpin effective and efficient social performance within organisations (Waithakam et al, 2013). Good corporate governance promotes goodwill and confidence in the financial system. Studies show that good corporate governance leads to increased valuation, higher profit levels, increased sales growth and lower capital expenditure (Wolfgang, 2003). This view way supported by Lam, Tin and Lee (2008). The main objective of the study is to evaluate the extent to which corporate governance affects delinquency management of microfinance banks in Nigeria. Specifically, the study investigates:

- the effects of board size on delinquency management of microfinance banks;

- analyses the impact of board composition on delinquency management of microfinance banks in Nigeria.

The other sections are divided into literature review, methodology, results and discussion as well as conclusion and recommendations. 
INTERNATIONAL JOURNAL OF ACADEMIC RESEARCH IN BUSINESS AND SOCIAL SCIENCES

Vol. 10, No. 5, May, 2020, E-ISSN: 2222-6990 @ 2020 HRMARS

\section{Literature Review}

\section{Conceptual Clarifications}

\section{Corporate Governance}

Alexandra, Reed, and Lajoux (2005) define corporate governance as the system by which companies are directed and controlled. The nature of corporate governance, therefore, going by this definition consists of two dimensions: direction and control. The direction dimension of corporate governance emphasises the responsibility of the board to attend to strategic positioning and planning in order to enhance the performance and sustainability of the company; while on the other hand, emphasises the responsibility of the board to oversee the executive management of the company in the execution of the plans and strategies. Sequel to the financial crisis in 2006 to 2007 witnessed all over the world especially in the banking sector, the issue of corporate governance has become an issue to talk about in both non academic settings and academic environment. Most studies have defined corporate governance in different ways especially as it concerns power of owners, managers and providers of capital (Solomon, 2010).

The concept of corporate governance is viewed from two perspectives, namely, the narrow and broad perspectives. The narrow approach to corporate governance is viewed by Arun and Turner (2002) as the mechanism through which shareholders are assured that managers will act in their interest. Oyejide and Soyibo (2001) explain this narrow view of corporate governance as the relationship of the enterprise to shareholders. It is concerned with the structures within which a corporate entity or enterprise receives its basic orientation and direction. Shleifer and Vishny (1997) contend that corporate governance mainly deals with the ways in which the returns on investment of shareholders of an organisation are guaranteed. Similarly, Cadbury, Butler, Lipworth, Macdonald, Smith, Brown and Collum (1992) also narrowly describe corporate governance as an arrangement through which the affairs of shareholders are managed and controlled. Furthermore, Hart (1995) sees corporate governance as the interaction involving shareholders and the senior management of companies with board of directors acting as the mediator. According to Pandey (2006), corporate governance is a process that ensures responsibility, transparency and accountability functions of management in order to maximise shareholders wealth and take decisions to boost its financial performance.

The broad view of corporate governance is concerned with the methods by which suppliers of finance control managers in order to ensure that their capital cannot be expropriated and that they earn a return on their investment. It views corporate governance as the relationship of the enterprise to society as a whole (Angahar \& Mejabi, 2014). According to Oyejide and Soyibo, (2001), the broad perspective of corporate governance is described as being the heart of both a market economy and democratic society. Corporate governance entails incorporating the interest of stakeholders such as management, shareholders, customers, creditors, government and other stakeholders in the affairs of the organisation. In this regard, corporate governance is defined as a set of institutional arrangements for governing the interest of all the stakeholders who have contributed in one way or the other (Blair, 1995; Obasi \& Nkwagu, 2017). Rogers (2008) opines that corporate governance is about building credibility, ensuring transparency and accountability as well as maintaining an effective channel of information disclosure that would foster good corporate performance. Roger (2008) further opines that it is about how to build trust and sustain confidence among the various interest groups that make up an organisation.

Similarly, Salvioni, Gennari and Bosetti (2016) posit that corporate governance is a combination of structures and processes. While the structure refers to all the bodies responsible for the firm's 
direction and control, the processes consist in the activities developed to satisfy the stakeholders' expectation. Corporate governance, therefore, specifies the ways by which corporations are directed and guarded. The structure of corporate governance outlines the way in which stakeholders' rights and responsibilities are shared and distributed. Corporate governance provide a framework through which management and boards provide a transparent, fair and efficient environment that are needed to satisfy the interest of all the stakeholders (management, supplier of capital, government, creditors, the host communities, depositors and other stakeholders) as well as to achieve the long run goals of an organisation while complying with the regulatory and legal requirements of the industry (Bairathi, 2009).

In the case of banking institutions, the broader view of corporate governance is adopted because of the peculiar contractual form of banking which demands that corporate governance mechanisms for banks should encapsulate depositors as well as shareholders (Macey \& Hara, 2010). Macey and Hara (2010) support Arun and Turner (2002) by arguing that the special nature of banking requires not only a broader view of corporate governance, but also government intervention in order to restrain the behaviour of bank management.

The aim of corporate governance is to ensure that corporations are managed in the best interests of their owners and shareholders (Ahmed, Alam, Jafar \& Zaman, 2008). This applies specifically to listed companies where the majority of the shareholders are not in participatory everyday management positions; although, it can also apply to other forms of corporations such as companies with few principal owners and a large group of smaller shareholders, public corporations (where all citizens are stakeholders) partner-owned companies and privately owned companies where the ownership has been divided through inheritance in one or several generations (Ahmed, Alam, Jafar \& Zaman, 2008). It is, therefore, concluded that corporate governance ensures transparency, investor protection, full disclosure of executive actions and corporate activities to stakeholders, environmental impact assessment of corporate activities, assurance of performance related to executive compensation and full disclosure of executive compensation.

\section{Delinquency Management}

According to CGAP (2009), the delinquency can be analysed by looking at three broad indicators. These include collection rates which measure the amount of money over schedule for payment by the customers (clients) as against the amount of loan issued out; arrears rates measure overdue amounts against total loan amounts and risk rate of the portfolio measures the unpaid loans balance that were not settled on time by the clients against total loans balances. Delinquency arises when there is an increased loss of credit risk and cautions of operational challenges. The measurement of delinquency helps to project how much of the portfolio will not be retrieved from the clients or otherwise will never be repaid by the customers (CGAP, 2009). Agene (2011) explains credit risk portfolio as the worsening of the quality of loan portfolio leading to losses of loan from clients and rising delinquency cost of management.

For purposes of managing delinquent loans, microfinance institution should categorise loans into five loan portfolios and also make provision for bad debt. These categories include performing, watchunpaid unto 30 days, substandard -unpaid up to 180 days, Doubtful-unpaid up to 360 days and Lossunpaid for over 360 days. These classifications will help delinquency management on loans portfolios' to be effective (Lillian, 2013). Kohansal and Mansoori (2009) observe that lenders devise various institutional mechanisms aimed at managing loan default. These include pledging of collateral, third- 
party credit guarantee, use of credit rating and collection agencies, etc. Aballey (2009) states that bad loans delinquent can be managed by ensuring that loans are made to only borrowers who are likely to be able to repay, and who are unlikely to become insolvent.

Credit analysis of potential borrowers should be carried out in order to judge the credit risk with the borrower and to reach a lending decision. Loan repayments should be monitored and whenever a customer defaults, actions should be taken. Thus banks should avoid loans to risky customers, monitor loan repayments and renegotiate loans when customers get into difficulties (AmeyawAmankwah, 2011). MFIs need a monitoring system that highlights repayment problems clearly and quickly, so that loan officers and their supervisors can focus on delinquency before it gets out of hand (Warue, 2012). Sheila (2011) is of the view that proper and adequate appraisal is key to controlling or minimising default. This is the basic stage in the lending process. According to Anjichi (1994), the appraisal stage is the heart of a high quality portfolio. This includes diagnosing of the business as well as the borrower. Before beginning the process of collecting information on the client for the purpose of determining credit limits, the loan officer should have specific information available which will guarantee that the data and figures provided by the client will have a pro-margin error (Sheila, 2011).

\section{Theoretical Review}

\section{Agency Theory}

Agency theory was propounded by Jensen and Meckling (1976). Agency theory explains the relationship or the interaction between the principal and the agent. This theory postulates that employees must constitute a good governance structure since they are held accountable in their tasks and responsibilities. This theory prescribes that people or employees are held accountable in their tasks and responsibilities. Employees must constitute a good governance structure rather than just providing the need of shareholders, which may be challenging to the governance structure.

\section{Stewardship Theory}

Stewardship theory was developed by Donaldson and Davis $(1991,1993)$ as a new perspective to understand the existing relationship between ownership and management of the company. The theory recognises the importance of governance structures that empower the steward and offers maximum autonomy built on trust. It stresses the position of employee to act more autonomously so that the shareholders' returns are maximised. Indeed, this can minimise the costs aimed at monitoring and controlling employee behaviour (Davis et al., 1997). Daily et al. (2003) assert that in order to protect their reputations as decision makers in organisations, managers are inclined to operate the firm to maximise financial performance as well as shareholders' profits.

\section{Empirical Studies}

Choudhry (2011) applied content analysis to disclose the extent and length to which inappropriate corporate governance contributed to the financial market crash in Western Europe and North America. The study found that the nature and composition of Boards was not robust enough to provide independent direction. Their membership possessed lack of quality expertise, and was not geared towards a long-term view of the bank's development. Consequently many banks were drawn into a bull market spiral. It was observed that the study failed to employ the use of questionnaire as an instrument other than relying on review of past literature. Onakoya, Ofoegbu and Fasanya (2011) sample six selected banks from the year 2005 to 2009 to review the impact of corporate governance 
on bank performance in Nigeria with the aid of pooled time series data. The study made use of corporate governance, inflation, interest rate policy reform and real gross domestic product on profit after tax. Findings from the pooled data reveal that all the variables has negative effect on bank performance which indicates that corporate governance have been on the low side and has impacted negatively on bank performance. It is observed from the study that the variables used do not have capacity to measure corporate governance on bank performance which attributed to the negative effect on bank performance.

Mohammed (2011) employs chi-square statistical method of inferential statistics to analyse the role of corporate governance on the performance of banks in Nigeria between the periods of five years (2003-2007). The findings of the study show that the independence of audit committees significantly influences financial performance of banks (return on asset) in Nigeria. It is therefore, observed, that using only independence of audit committees as a proxy for corporate governance is not sufficient and robust enough, as if that is the only variable that captures corporate governance. Also, the method applied may be inappropriate, in that the study could have employed panel data regression since it has cross-sectional data. Ajala, Amuda and Arulogun (2012) apply Pearson Correlation and regression analysis to examine the effects of corporate governance on the performance of Nigerian banking sector. The study reveals that there exists negative but significant relationship between board size and the financial performance of these banks while a positive and significant relationship was also observed between directors' equity interest, level of corporate governance disclosure index and performance of the sampled banks.

Adeusi, Akeke, Aribaba and Adebisi (2013) use sample of 10 selected banks' annual reports covering 2005-2010 to examine the relationship between corporate governance and performance in Nigerian banking sector. The study used return on asset, board size, board composition, that is, number of executive directors and number of non-executive directors. The study concludes that there is a need for increase in board size and decrease in board composition as measured by the ratio of outside directors to the total number of directors in order to increase the bank's performance. Emeka and Alem (2016) investigate the effect of corporate governance on financial performance of banks in Nigeria over a sample of 10 selected banks for the years covering 2004 to 2013. Panel regression estimate was employed and revealed that the relationship between corporate governance and bank performance in Nigeria is quite significant as a unit change in the board size and the relative size of non-executive directors increases the return on assets. The study therefore concludes that proper structuring of the stakeholders in the corporate governance team is a panacea to the perennial banking crisis experienced in Nigeria. Akintoye and lyaniwura (2017) evaluate Nigeria's corporate governance regime and explores how weak regulation has impacted on the banking sector. By adopting a socio legal methodology, the study analyses both theoretical and empirical works from a socio-scientific point of view to examine the role of Nigeria's legal, cultural and social arrangements in corporate governance regulation. The study reveals that Nigeria's institutional arrangement has contributed to its weak system of corporate governance regulation with adverse effects on the banking sector. It is observed that the study mainly impacts on current global corporate governance literature in sub-Saharan Africa by contributing to knowledge of the peculiarities of corporate governance regulation in different institutional jurisdictions.

Nkwati and Akame (2017) assess the nexus between corporate governance and performance of credit unions in Cameroon. The Principal Component Analysis (PCA) was employed and showed that board role and composition have positive and significant effect on loan portfolio and profitability of credit 
INTERNATIONAL JOURNAL OF ACADEMIC RESEARCH IN BUSINESS AND SOCIAL SCIENCES Vol. 10, No. 5, May, 2020, E-ISSN: 2222-6990 @ 2020 HRMARS

unions but effect on the liquidity and overall financial performance was insignificant. Meanwhile, it was found that transparency and disclosure, auditing and compliance as well as risk management had positive and significant effects on all aspects of financial performance (Loan Portfolio, Liquidity and profitability) as well as overall financial performance of credit unions. The study is purely centred on corporate governance and financial performance of microfinance neglecting loan delinquent as if micro-credit institutions are not exposed and more vulnerable to loan delinquency. Igbekoyi and Agbaje (2018) investigate the effect of corporate governance on the quality of accounting information disclosed in Nigerian banks during the period of 2006-2015. Data were analysed using co-integration and error correction model. The study shows that Audit committee meeting (ACM), Audit committee qualification (ACQ), Board size (BS), Directors in audit committee (DAC) and Ownership structure (OS) have a significant positive relationship with accounting information disclosure at $1 \%$ and $5 \%$ level of significance respectively, while Corporate board members (CBM) had an insignificant negative relationship with accounting information disclosure in Nigeria. Based on the finding of the study, it is concluded that corporate governance contributes to the quality of accounting information disclosed in the banking sector. Lestari (2018) analyses the effect of corporate governance, bank capital reserve, and non performing loan on bank risk taking listed in Indonesia Stock Exchange from 2009 to 2016. Using regression analysis, the study found that ownership concentration, the big four audit committee, and non-performing loan have negative effects on bank's risk taking behaviour while capital reserve is not statistically significant on bank risk taking.

\section{Methodology}

\section{Research Design, Population, Sample and Sampling Technique of the Study}

This study adopted ex-post-factor research design in which investigation starts after the fact has occurred without interference from researcher. The population of this study consisted of 337 microfinance banks in Southwest, Nigeria which comprises 5 National, 34 State and 298 unit microfinance banks (CBN, 2017). Convenient sampling technique is adopted in the research to select thirty microfinance banks from the population in Southwest on the basis that any chosen bank must have been in operation for at least 7 years which constitute the scope of the study especially from 2012 to 2018. In order to ensure accuracy, validity and reliability of data, thereby eliminating chances of errors and bias in selection process, and due to recent closure and license revocation of some microfinance banks by CBN, thirty (30) microfinance banks are randomly chosen based on 5 microfinance banks per state in Southwest.

Hence, the microfinance Banks considered for the study include: (AB Microfinance Bank; Accion microfinance Bank; NPF microfinance Bank; B. C. KASH microfinance Bank and FBN microfinance Bank for Lagos State; Covenant microfinance Bank; Ajose microfinance Bank; Babcock microfinance Bank; Ilaro Polytechnic microfinance Bank and MAPOLY microfinance Bank for Ogun State; Caretaker Microfinance Bank; Excel microfinance Bank; FCMB microfinance Bank; Ifedapo microfinance Bank and Unilbadan microfinance Bank for Oyo state; First access microfinance Bank; Ikire microfinance Bank; OSCT microfinance Bank; Pathfinder microfinance Bank and Olofin-Owena microfinance Bank for Osun State; Ekimogun microfinance Bank; Fasidapo microfinance Bank; Lavelu microfinance Bank; New age microfinance Bank and Shield microfinance Bank for Ondo State; Consistent Trust microfinance Bank; Harvest microfinance Bank; Transwealth microfinance Bank; Ulayin microfinance 
INTERNATIONAL JOURNAL OF ACADEMIC RESEARCH IN BUSINESS AND SOCIAL SCIENCES

Vol. 10, No. 5, May, 2020, E-ISSN: 2222-6990 @ 2020 HRMARS

Bank and Omiye microfinance Bank for Ekiti State). The choice of these microfinance Banks came to be as a result of large number of customer patronising their services.

\section{Model Specification and Estimation Technique}

The study examines the effects of corporate governance on delinquency management of microfinance banks in Southwest, Nigeria. From review of literatures, Emeka and Alem's (2016) on corporate governance and financial performance of banks is identified as the basis for this study.

Emeka and Alem's (2016) model is stated as;

$R O A=f(B S I Z E, B C O M)$

Where:

ROA = Return on asset

$\mathrm{BSIZE}=$ Board size

BCOM = board composition

$f=$ Functional notation

This study adapts the models by replacing return on asset variable with delinquency management (DM) proxied by default rate (DR). The justification for inclusion of percentage of default rate in the model is that the proxy directly measure delinquency management as introduced by MCP (2010) while return on asset measures firm's performance.

Hence, the main model for the study is stated as:

$D R=f(B S, B C)$

Where;

$\mathrm{DR}=$ Loan portfolio at risk

$\mathrm{BS}=$ Board size

$\mathrm{BC}=$ Board composition

$f=$ Functional notation

Static panel regression is used as data analysis method for the study. The use of static panel regression analysis in the study is based on three fundamental justifications. (1) The data collected had time and cross sectional attributes and this enabled the researcher to study corporate performance over time (time series) as well as across the sampled quoted companies (cross-section). (2) Panel data regression provide better results since it increases sample size and reduces the problem of degree of freedom. (3) The use of panel regression would avoid the problem of multicollinearity, aggregation bias and endogeneity problems (Solomon, et al., 2012). However, the static panel regression consists of pooled data analysis which neglects the heterogeneity effects in the sampled companies, the fixed panel regression analysis which assumes that there is a correlation between the independent variables in each model and their panel error terms and the random panel regression analysis which assume that there is no correlation between the independent variables in each model and their panel error terms. In any case, the study uses the Hausman test to select between fixed and random panel estimation techniques.

The regression test is stated as:

$D M=\alpha_{0}+\alpha_{1} B S+\alpha_{2} B C+\mu_{t}$

Where;

$\alpha_{0}=$ constant term

$\alpha_{1}-\alpha_{2}=$ Coefficient of the parameters

$\mu_{t}=$ error term 
INTERNATIONAL JOURNAL OF ACADEMIC RESEARCH IN BUSINESS AND SOCIAL SCIENCES

Vol. 10, No. 5, May, 2020, E-ISSN: 2222-6990 @ 2020 HRMARS

$t=$ time series

Other variables remained as earlier defined.

\section{The Fixed Effect Model}

The term "fixed effect" is due to the fact that although the intercept may differ among firms, each firm's does not vary overtime, that is time-variant. This is the major assumption under this model i.e. while the intercept are cross-sectional variant, they are time variant.

In the least squares dummy variable (LSDV) regression model, the unobserved effect is brought explicitly into the model. If we define a set of dummy variables $A_{i}$, where $A_{i}$ is equal to 1 in the case of an observation relating to firm $i$ and $O$ otherwise, the model can be written

$$
\mathrm{Y}_{\mathrm{it}}=\sum_{j=2}^{k} \beta_{j} X_{i j t}+ð \mathrm{t}+\sum_{t=1}^{n} \infty_{i} A_{i}+\mathrm{E}_{\mathrm{it}}
$$

Formally, the unobserved effect is now being treated as the co-efficient of the individual specific dummy variable.

\section{Random Effect Model}

Random effects regression model is subject to two conditions: the first condition is that it is possible to treat each of the first unobserved $Z_{p}$ variables as being drawn randomly from a given distribution. This may well be the case if the individual observations constitute a random sample from a given population.

If $\mathrm{Y}_{\mathrm{it}}=\beta_{j}+\sum_{j=2}^{k} \beta_{j} X_{i j t}+ð_{\mathrm{t}}+\infty_{i}+\mathrm{E}_{\mathrm{it}}=\beta_{i}+\sum_{j=2}^{k} \beta_{j} X_{i j t}+ð_{\mathrm{t}}+\mu_{\mathrm{it}}$

where: $\mu_{i t}=\infty_{\mathrm{i}}+\mathrm{E}_{\mathrm{it}}$

The unobserved effect has been dealt with by subsuming it into the disturbance term.

The second condition is that the $Z_{p}$ variables are distributed independently of all the $X_{j}$ variables. If this is not the case, $\infty$, and here $\mu$, will not be uncorrelated with $X_{j}$ variables and the random effects estimation will be biased and inconsistent. 
INTERNATIONAL JOURNAL OF ACADEMIC RESEARCH IN BUSINESS AND SOCIAL SCIENCES Vol. 10, No. 5, May, 2020, E-ISSN: 2222-6990 @ 2020 HRMARS

Measurement of Variables, Sources of Data and Apriori Expectation

Table 1: Description of Variables and Source of Data

\begin{tabular}{|l|l|l|l|}
\hline Variable & Formulae & Measurement/Description & Source \\
\hline $\begin{array}{l}\text { Delinquency } \\
\text { management }\end{array}$ & Default rate & $\begin{array}{l}\text { Default rate (DR) is the term for a } \\
\text { practice in the financial services } \\
\text { industry for a particular lender to } \\
\text { change the terms of a loan from the } \\
\text { normal terms, to the default terms } \\
\text { that is, the terms and rates given to } \\
\text { those who have missed payments on } \\
\text { loan. Default rate ratio = Non } \\
\text { Performing Loans/ Total loan }\end{array}$ & $\begin{array}{l}\text { Annual } \\
\text { statement } \\
\text { account }\end{array}$ \\
\hline Corporate governance & Board Size & $\begin{array}{l}\text { Board size is measured as the number } \\
\text { of people on the board of the firm. }\end{array}$ & $\begin{array}{l}\text { Annual } \\
\text { statement } \\
\text { of } \\
\text { account }\end{array}$ \\
\hline Corporate governance & Board Composition & $\begin{array}{l}\text { Board composition is measured by the } \\
\text { proportion of non-executive directors } \\
\text { on board, and is calculated as the } \\
\text { number of non-executive directors } \\
\text { divided by total number of directors. }\end{array}$ & $\begin{array}{l}\text { Annal } \\
\text { statement } \\
\text { account }\end{array}$ \\
\hline
\end{tabular}

Source: Author's compilation (2020)

It is expected that at the end of the analysis, board size (BS), board composition (BC) may have positive or negative relationship with the dependent variable delinquency management (DM) depending on composition of board members and size. In other words, an increase in BS and BC by one unit should lead to a corresponding increase or decrease in the dependent variable DM in the same direction. From the above explanation, it can be summarised thus;

$\frac{\partial D M}{\partial B S}>0 ; \frac{\partial D M}{\partial B C}>0$

\section{Result and Discussion}

Pooled OLS Analysis

Table 1 Pooled OLS Estimation Result (Cross-sectional and Period specific) of Corporate Governance and Delinquency Management (Default Rate)

Series: $D R, B S, B C, C S, C T$

\begin{tabular}{|c|r|r|r|r|}
\hline Variable & Coefficient & Std. Error & t-Statistic & Prob. \\
\hline C (DR) & 0.327768 & 0.339971 & 0.964105 & 0.3361 \\
\hline BS & 0.505655 & 0.195076 & 2.592095 & 0.0102 \\
\hline BC & 0.122024 & 0.341098 & 0.357738 & 0.7209 \\
\hline R-squared & 0.800657 & F-statistic & 13.579522 \\
\hline Adjusted R-squared & 0.689124 & Prob(F-statistic) & 0.000197 \\
\hline S.E. of regression & 0.546170 & Durbin-Watson stat & 1.317614 \\
\hline
\end{tabular}

Source: Author's Computation, (2020) from E-view 9 
INTERNATIONAL JOURNAL OF ACADEMIC RESEARCH IN BUSINESS AND SOCIAL SCIENCES Vol. 10, No. 5, May, 2020, E-ISSN: 2222-6990 @ 2020 HRMARS

Pooled estimation result presented in Table 1 reveals that when heterogeneity effect across microfinance banks sampled in the study is not given consideration, board size exerts a significant and positive effect on default rate with coefficient of $0.505655(p=0.0102>0.05)$. Board composition reveals a positive and insignificant impact on default rate with coefficient estimate of 0.122024 $(p=0.7209>0.05)$. Adjusted R-square statistics reported in Table 1 shows that about $69.91 \%$ of the systematic variation in default rate can be jointly explained by board size and board composition. The F-statistics value of 13.579522 with the probability of F-statistics value of $0.000<0.05$ showed that the fitted regression model is statistically significant and thus appropriate, reliable and acceptable for assessing the effect of corporate governance, and delinquency management in Nigeria.

\section{Fixed Effect Estimation}

Table 2: Fixed Effects Estimates (Cross-sectional and Period specific) of Corporate Governance and Delinquency Management (Default Rate)

Series: $D R, B S, B C, C S, C T$

\begin{tabular}{|c|c|c|c|c|c|}
\hline \multicolumn{2}{|c|}{ CROSS-SECTIONAL SPECIFIC EFFECT } & \multicolumn{3}{c|}{ TIME SPECIFIC EFFECT } \\
\hline Variables & Coefficients & Prob & Variables & Coefficients & Prob \\
\hline C & 5.755882 & 0.0000 & C & -0.507339 & 0.0000 \\
\hline BS & -0.197453 & 0.0319 & BS & 0.105382 & 0.4100 \\
\hline BC & -0.050505 & 0.9388 & BC & 0.121663 & 0.0817 \\
\hline $\begin{array}{l}\text { R-square = 0.893559 } \\
\text { Adjusted R-square = 0.868366 }\end{array}$ & R-square $=0.606224$ \\
F-statistics = 35.46838 & Adjusted R-square $=0.570427$ \\
Prob(F-stat) = 0.000000 & F-statistics $=16.93470$ \\
\hline
\end{tabular}

Source: Author's Computation, (2020) from E-view 9

Fixed effect cross-sectional specific estimation result presented in Table 2 shows that when heterogeneity effect across microfinance banks sampled in the study is incorporated into the model, board size and board composition have negative with a significant effect on delinquency management measured by default rate. Reported coefficient estimate for board size and board composition stands at $-0.197453(\mathrm{p}=0.0319<0.05)$, and $-0.050505(\mathrm{p}=0.9388>0.05)$ respectively. Adjusted R-square value reported for cross-sectional specific estimation presented in Table 4.8 stands at 0.868366 , which reflects that about $86.83 \%$ of the systematic variation in default rate can be explained jointly by the explanatory variables. Result of fixed effect period-specific estimation presented in Table 2 shows that when heterogeneity effect over time is incorporated into the model as intercept term, board size has positive with an insignificant effect on default rate with the coefficient of $0.105382(p=0.410>0.05)$, board composition has positive with an insignificant effect on default rate with coefficient of $0.121663(p=0.081>0.05)$. 
INTERNATIONAL JOURNAL OF ACADEMIC RESEARCH IN BUSINESS AND SOCIAL SCIENCES Vol. 10, No. 5, May, 2020, E-ISSN: 2222-6990 @ 2020 HRMARS

\section{Random Effect Estimation}

Table 3 Random Effect Estimation of Corporate Governance and Delinquency Management (Default rate)

Series: $D R, B S, B C, C S, C T$

\begin{tabular}{|c|r|r|r|r|}
\hline Variable & Coefficient & Standard Error & T-Test Values & \multicolumn{1}{l|}{ Probability } \\
\hline C & 4.523011 & 0.944071 & 4.790965 & 0.0000 \\
\hline BS & -0.183129 & 0.011468 & -15.96851 & 0.0000 \\
\hline BC & -0.321487 & 0.642455 & -0.500404 & 0.6174 \\
\hline $\begin{array}{l}\text { R-square }=0.883946 ; \text { Adjusted R-square }=0.861398 ; \text { F-statistic = 39.20344; } \\
\text { Prob(F-statistic) }=0.000000 ; \text { Durbin-Watson stat = 2.181888 }\end{array}$ \\
\hline
\end{tabular}

Source: Author's Computation, (2020) from E-view 9

Random effect estimation result presented in Table 3 reveals that when heterogeneity effect across microfinance banks and over time is incorporated into the model via the error term, both board size and board composition have negative effect on default rate, however, board size has significant effect while board composition has insignificant effect respectively given the reported estimates for board size that stands at $-0.183129(p=0.00<0.05)$, as against estimate for board composition that stand at $-0.321487(p=0.61>0.05)$. Reported R-square for random effect estimation presented in Table 4.9 stands at 0.883946 which implies that about $88 \%$ of the explanatory variables contributes to default rate. The coefficient of adjusted R-square is 0.861398 which implied that the systematic variation in default rate can be explained by board size and board composition of the sampled microfinance banks in Nigeria. The F-statistics value of 39.20344 with the probability value of $0.000<0.05$ shows that the random regression model is statistically significant and thus appropriate, reliable and acceptable for assessing the effect of corporate governance on delinquency management among selected microfinance banks in Nigeria. More so, the Durbin Watson test statistics of 2.18 explored that the model is free from any serial autocorrelation.

\section{Hausman's Test}

Table 4 Hausman Test

\begin{tabular}{|l|l|l|}
\hline Null hypothesis & Chi-square stat & Probability \\
\hline Difference in coefficient not systematic & 12.801303 & 0.5253 \\
\hline
\end{tabular}

Source: Author's Computation, (2020) from E-view 9

Table 4 reported chi-square statistics of 12.80 and probability value of 0.5253 . The result revealed that there is no enough evidence to reject the null hypothesis that differences in coefficients of fixed effect estimation and random effect estimation is not significant. Therefore, the most consistent and efficient estimation is given by the random effect estimation as presented in Table 4. It thus becomes evident that the estimation that best explains the effects of corporate governance on delinquency management of microfinance banks in Nigeria as measured in terms of default rate is the random effect estimation presented in Table 3, which revealed that board size and board composition have negative effect on default rate, however, board size has significant effect while board composition has insignificant effect respectively given the reported estimates for board size that stands at - 
INTERNATIONAL JOURNAL OF ACADEMIC RESEARCH IN BUSINESS AND SOCIAL SCIENCES

Vol. 10, No. 5, May, 2020, E-ISSN: 2222-6990 @ 2020 HRMARS

$0.183129(p=0.00<0.05)$, as against estimate for board composition that stands at $-0.321487(p=0.61$ $>0.05)$.

\section{Discussion of Finding}

Based on the result of the objectives, the study found that board size has a negative and significant effect on default rate by $18.31 \%$. The study also found that board composition has an insignificant negative effect on default rate, this implies that board composition contributes negatively to delinquency management by $32.15 \%$. Thus, the result of objective one indicates that board size has a negative but with a significant effect on delinquency management of microfinance banks in Nigeria. This implies that there are not too many directors on the board of microfinance banks in Nigeria, however as the number of directors on the board increases, the rate of loan delinquency has tendency to fall and vice versa. The result failed to conform with the apriori of positive expectation on delinquency management of microfinance banks, nonetheless, the significant effect implies that banks with larger board size leads to slower and less-efficient decision-making processes which causes communication problems and hence negatively affects the banks' performance. This finding suggests that a smaller board size can enhance banks' performance by reducing loan default rate as the smaller size can take quick and adequate decision for the performance of the banks as large boardrooms tend to be slow in making decisions, and hence can be an obstacle to change. The negative but significant relationship found between board size and delinquency management is consistent with the conclusions drawn by Uwuigbe (2011), and Ajala, Amuda and Arulogun (2012).

Secondly, the result on objective two reveals that board composition has an inverse with an insignificant effect on delinquency management of microfinance banks in Nigeria. This implies that lesser presence of non-executives or independent members in their board may not be able to protect their reputations as effective, independent decision makers. More so, it implies that non-executive directors are likely not to have a hands-on approach or are not necessarily well versed in the operations of the institution, hence, do not necessarily make the best decisions. Thus, the need for larger number of non-executive or independent director as board members. This implies that as the number of non-executive directors increases in greater proportion to the executive directors, loan delinquency may decreases. The result is not in conformity with the positive apriori expectation; it is also at variance with the positive relationship evidenced in the empirical finding of Emeka and Alem (2016), Nkwati and Akame (2017) but consistent with the negative relationship found in the empirical finding of Uwuigbe (2011), Oyewole et al (2015).

\section{Conclusion}

The study investigated the effects of corporate governance on delinquency of Microfinance banks in Southwest, Nigeria. Statistical evidence establishes that corporate governance has negative effects on delinquency management. It has been established in the literature that corporate governance affects stakeholders and the banks as a whole, corporate governance affects the potential or ability of a bank to reach its market share both domestically and globally; corporate governance also determines the banks' ability to fulfill its social objectives with its clientele and society at large (Emeka \& Alem, 2016). This study has, however, established that corporate governance practices when measured by board size have significant though with a negative effect on delinquency management of microfinance banks. However, when measured by board composition, it has a negative with an insignificant effects on delinquency management. The study, therefore, concludes that corporate 
governance has negative effect on delinquency management of microfinance banks in Nigeria. The study recommends that management of Microfinance banks should engage in the development and implementation of strategic training for board members and senior bank managers. They should regulate the size of the board which should not be too large and must consist of highly skilled and competent professionals who are conversant with oversight function; it is also suggested that banks should develop corporate governance policies for the appointment of independent board members, establish and maintain better relations with their stakeholders, and establish the unitary model of board system, in accordance with existing legal provisions.

\section{Contributions to Knowledge}

The study contributes to knowledge by employing the variables of board size and composition as relatively used in literature. Moreso, the study indicated that a negative relationship exists between corporate governance and delinquency management of microfinance banks in Nigeria. The study further contributes to theories that people or employees are held accountable in their tasks and responsibilities, as such, firm's performance can directly impact perceptions of their individual performance.

\section{References}

Aballey, F. B. (2009). Bad loans portfolio: The case of Agricultural Development Bank, Unpublished Dissertation.

Adeusi, S. O., Akeke, N. I., Aribaba, F. O., \& Adebisi, O. S. (2013). Corporate governance and firm financial performance: Do ownership and board size matter? Academic Journal of Interdisciplinary Studies, 2(3), 251-258.

Agene, A. (2011). The cause of loan default in microfinance bank. IOSR Journal of Business and Management, 16(2), 12-28.

Ahmed, H. L., Alam, M., Jafar, S. A., \& Zaman, H. (2008). A conceptual review on corporate governance and its effect on firm's performance: Bangladesh perspective. AIUB Bus Econ working paper series, 10, 1-24.

Ajala, O. A., Amuda, T., \& Arulogun, L. (2012). Evaluating the effects of corporate governance on the performance of Nigerian banking sector. Review of Contemporary Business Research, 1(1), 3242.

Akintoye, S. I., \& Iyaniwura, S. K. (2017). The impact of corporate governance regulation in the Nigerian banking sector. World Academy of Science, Engineering and Technology International Journal of Economics and Management Engineering, 11(4), 879-885.

Alexandra, C., Reed, K., \& Lajoux, O. (2005). Linkages between the quality of corporate governance and firm's performance. Workshop paper organized by the Asian Development Bank Institute.

Aliu, J. N., \& Gakure, R. W. (2014). The effects of corporate governance and sustainability of microfinance banks (MFBs) on entrepreneurs and SMEs in Northern Nigeria. International Journal of Entrepreneurial Development, Education and Science Research, 2(1), 1-10.

Ameyaw-Amankwah, I. (2011). Causes and effects of loan defaults on the profitability of Okomfo Anokye Rural Bank. Retrieved on January 5, 2015 from http://ir.knust.edu.gh/bitstream/123456789/4377/1/Isaiah\%20Ameyaw-Amankwah.pdf. 
INTERNATIONAL JOURNAL OF ACADEMIC RESEARCH IN BUSINESS AND SOCIAL SCIENCES

Vol. 10, No. 5, May, 2020, E-ISSN: 2222-6990 @ 2020 HRMARS

Angahar, P. A., \& Mejabi, S. K. (2014). The impact of corporate governance variables on nonperforming loans of Nigerian deposit money banks. Asian Economic and Financial Review, 4(11), 1531-1544.

Anjichi, S. N. (1994) Commercial banks lending techniques paper presented at the 10th East Central Banking course. Kampala in June.

Arun, O. J., \& Turner, K. S. (2002). Practice and standard of corporate governance in the Nigerian banking industry. International Journal of Economics and Finance, 2(4), 22 -31.

Bairathi, V. (2009). Corporate governance: A suggestive code. International Research Journal, 11(6), 735-754.

Blair, M. (1995). Ownership and control: Rethinking corporate for the twenty-first century: Brookings Institution, Washington DC.

Brownbridge, D. L. (2007). Corporate governance and firm performance, working paper, Georgia State University. Atlanta, GA.

Cadbury, A., Butler, J., Lipworth, S., Macdonald, N., Smith, A. H., Brown, S., Collum, H. (1992). Committees on the financial aspects of corporate governance. Gee, London.

CBN. (2017). Central Bank of Nigeria annual publication.

CGAP. (2009). Due diligence guidelines for the review of microfinance loan portfolios. USA: Washington D. C.

Choudhry, M. (2011). Effective bank corporate governance: observations from the market crash and recommendations for policy. Journal of Applied Finance \& Banking, I(1), 179-211.

Cicea, C., \& Hincu, D. (2009). Performance evaluation methods in commercial banks and associated risks for managing assets and liabilities. Communications of the IBIMA, 7, 1-13.

Ditcher, S. (2003). Micro finances double bottom line. The relationship lending constructs. Journal of Microfinance, 1(7), 5-13.

Donaldson, L. (2003). Boards and company performance: research challenges the conventional wisdom', corporate governance. An International Review, 2(3), 51-60.

Donaldson, L., \& Davis, J. (1991). Stewardship theory or agency theory: CEO governance and shareholder returns. Academy of Management Review, 20(1), 65-79.

Donaldson, T., \& Preston, L. E. (1995). The stakeholder theory of the corporation: Concepts, evidence and implications. Academy of Management Review 20(1), 65-91.

Emeka, E. E., \& Alem, I. E. B. (2016). The effect of corporate governance on bank's financial performance in Nigeria. Journal of Business and Management (IOSR-JBM), 18(11), 99-107.

Fernando, N. A. (2006). Understanding and dealing with high interest rates on microcredit. A note to policy makers in the Asia and Pacific Region. Asian Development Bank.

Hart, O. (1995). Corporate governance: Some theories and implications. The Economic Journal, 105:678-689.

Igbekoyi, O. E., \& Agbaje, W. H. (2018). Corporate governance and accounting information disclosure in the Nigerian banking sector. International Review of Business and Economics (IRBE), 2 (1), 27-48.

Jensen, M. C., \& Meckling, W. (1976). Theory of the firm: Managerial behaviour, agency costs and ownership structure. Journal of Financial Economics 3, 305-360.

Kohansal, M. R., \& Mansoori, H. (2009). Factors affecting loan repayment performance of farmers in Khorasan-razavi province of Iran. Conference on International Research on Food Security, Natural Resource Management and Rural Development, University of Hamburg, Germany. 
INTERNATIONAL JOURNAL OF ACADEMIC RESEARCH IN BUSINESS AND SOCIAL SCIENCES

Vol. 10, No. 5, May, 2020, E-ISSN: 2222-6990 @ 2020 HRMARS

Lam, T., Tin, S., \& Lee, T. S. (2008). CEO duality \& firm performance: Evidence from Hong Kong. Corporate Governance, 8(3), 299-316.

Lestari, D. (2018). Corporate governance, capital reserve, non-performing loan, and bank risk taking. International Journal of Economics and Financial Issues, 8(2), 25-32.

Lillian, K. (2013). The effect of credit risk management on loans portfolio among Saccos in Kenya. Unpublished MBA Thesis at the University of Nairobi, Kenya, 1-51.

Macey, K. S., \& Hara, O. (2010). Practice and standard of corporate governance in the Nigerian banking industry. International Journal of Economics and Finance, 2(4), 15 -24.

Moauro, A., \& Spaggiari, L. (2011). Motivating your board of directors to actively promote and deepen the social mission. Valladolid: MicroCredit Summit Campaign.

Mohammed, F. (2011). Impact of corporate governance on banking sector performance in Nigeria. International Journal of Economic Development Research and Investment, 2(2), 52-59.

Ndumai, C. N. (2013). Effect of corporate governance on credit risk management in commercial banks in Kenya. Unpublished Thesis submitted at University of Nairobi.

Nkwati, N. D., \& Akame, A. J. (2017). The impact of corporate governance on the financial performance of credit unions: The case of CamCCUL network. International Journal of Multidisciplinary Research and Development, 4(6), 233-243.

Obasi, A. I., \& Nkwagu, L. C. (2017). Effect of corporate governance on risk management of commercial banks in Nigeria. International Journal of Finance and Accounting, 6(5), 145-153.

Onakoya, A. B. O., Ofoegbu, D. I., \& Fasanya, I. O. (2011). Corporate governance and bank performance: A pooled study of selected banks in Nigeria. European Scientific Journal, 8(28), 155-164.

Oyejide, T., \& Soyibo, A. (2001). Corporate governance in Nigeria. Ibadan: Development Policy Centre, Nigeria.

Oyewole, O. S., Olusanmi, O., \& Owolabi, F. (2015). Role of corporate governance in the financial crisis; Evidence from Nigerian banks. Journal of Accounting and Auditing: Research \& Practice, 15(20),1-14.

Pandey, I. M. (2006). Financial management. Ninth edition, India, Vikas publishing house PVT Ltd.

Rogers, M. (2008). Corporate governance and financial performance of selected commercial banks in Uganda. A Paper presented at CRRC 2008, Queen's University, Belfast 7(9), 1-18.

Salvioni, D. M., Gennari, E., \& Bosetti, L. (2016). Sustainability and convergence: The future of corporate governance system? Sustainability, 8, 1203-1229.

Sheila, A. L. (2011). Lending methodologies and loan losses and default in a microfinance deposittaking institutions in Uganda. A case study of Finca Uganda Kabala Branch(MDI). Research report presented to Makerere University, Uganda.

Shleifer, A., \& Vishny, R. W. A. (1997). A survey of corporate governance. Journal of Financial Economics, 52(2), 737- 783.

Solomon, J. (2010). Corporate governance and accountability, Wiley.com.

Unegbu, O. C. K. (2004). Corporate Governance in Banking \& other Financial Institutions: Law, Issues and Ethics. The CIBN Press Ltd, Lagos.

Uwuigbe, O. R. (2011). Corporate governance and financial performance of banks: A study of listed banks in Nigeria. Covenant University, Ota.

Waithaka S. M., Kagure, R. W., \& Wanjau, K. (2013). The effects of leadership characteristics on microfinance institutions social performance in Kenya Nairobi, Kenya. 
INTERNATIONAL JOURNAL OF ACADEMIC RESEARCH IN BUSINESS AND SOCIAL SCIENCES Vol. 10, No. 5, May, 2020, E-ISSN: 2222-6990 @ 2020 HRMARS

Warue, B. N. (2012). Factors affecting loan delinquency in microfinance in Kenya. International Journal of Management Sciences and Business Research, 1(12), 1-15. 